Tri Inda Fadhila Rahma: Pengaruh Inflasi dan Suku Bunga

\title{
PENGARUH INFLASI DAN SUKU BUNGA TERHADAP BAGI HASIL BANK SYA- RIAH DI INDONESIA
}

\author{
Tri Inda Fadhila Rahma, M.E.I \\ Universitas Islam Negeri Sumatera Utara Medan
}

\begin{abstract}
Abstrak
Penelitian ini bertujuan untuk mengetahui berapa besar pengaruh Inflasi dan suku bunga terhadap bagi hasil bank syariah di Indonesia. Variabel penelitian ini adalah inflasi, suku bunga dan bagi hasil bank syariah dari bulan Januari tahun 2013 sampai bulan Juni tahun 2015. Desain penelitian bersifat kuantitatif dengan menggunakan teknik analisis regresi linier berganda dengan menggunakan bantuan program Eviews versi 7. Dari hasil penelitian yang dilakukan pada alpha $5 \%$, secara simultan variabel inflasi dan suku bunga berpengaruh terhadap bagi hasil bank syariah di Indonesia. Secara parsial inflasi tidak berpengaruh terhadap bagi hasil bank syariah. Sedangkan suku bunga terhadap bagi hasil bank syariah adalah positif dan signifikan, sehingga peningkatan suku bunga sebesar $1 \%$ akan menaikkan bagi hasil bank syariah sebesar 0,027078\%. Meningkatnya suku bunga akan meningkatkan bagi hasil bank syariah, karena peningkatan suku bunga akan membuat masyarakat akan beralih untuk mengajukan pembiayaan ke bank syariah dan tidak melakukan peminjaman uang kepada bank konvensional yang menawarkan bunga lebih besar dari return yang akan dikembalikan.
\end{abstract}

Kata Kunci : Bagi Hasil, Inflasi, Suku Bunga, Bank Syariah

\section{Pendahuluan}

Bank Islam merupakan lembaga keuangan yang usaha pokoknya memberikan pembiayaan dan jasa-jasa lainnya dalam lalu lintas pembayaran serta peredaran uang yang pengoperasiannya disesuaikan dengan prinsip syariat Islam (Muhammad, 2014). Perbankan syariah lebih dikenal dengan bank bagi hasil. Bank syariah tidak beroperasi dengan sistem bunga melainkan dengan sistem bagi hasil, yakni adanya kesepakatan berbagi keuntungan ataupun kerugian antara mitra kerja. Bagi hasil adalah bentuk return (perolehan aktivitas usaha) dari kontrak investasi dari waktu ke waktu, tidak pasti dan tidak tetap pada bank syariah. Besar kecilnya perolehan itu tergantung pada hasil usaha yang benar-benar diperoleh bank islam (Rivai, 2010). Bank syariah hanya menetapkan persentase pembagian atas keuntungan yang diperoleh, bukan persentase atas modal yang diberikan seperti halnya bank konvensional dengan sistem bunga.

Bank syariah dalam kegiatannya sama seperti bank konvensional, yakni menghimpun 
j-EBIS Vol. 3 No. 1 April 2018

dana dari masyarakat yang kelebihan dana dan menyalurkan dana kepada masyarakat yang kekurangan dana. Bank syariah menghimpun dana dalam bentuk tabungan, deposito dan giro dan menyalurkan dana dalam bentuk pembiayaan, jual beli dan sewa menyewa. Namun dalam produk perbankan syariah tidak memberikan return yang tetap seperti halnya dengan bank konvensional yang menjanjikan return yang tetap kepada masyarakat.

Bank syariah dalam kegiatan atau usaha yang dijalankan yakni memperoleh keuntungan dari pembiayaan dengan prinsip bagi hasil diperoleh keuntungan sesuai dengan kesepakatan (nisbah bagi hasil) dengan masing-masing nasabah (mudharib atau mitra usaha), dari pembiayaan dengan prinsip jual beli diperoleh margin keuntungan, sedangkan dari pembiayaan dengan prinsip sewa diperoleh pendapatan sewa. Keseluruhan pendapatan dari pooling fund ini kemudian dibagihasilkan antara bank dengan semua nasabah yang menitipkan, menabung, atau menginvestasikan uangnya sesuai dengan kesepakatan awal. Bagian nasabah atau hak pihak ketiga akan didistribusikan kepada nasabah, sedangkan bagian bank akan dimasukkan ke dalam laporan laba rugi sebagai pendapatan operasi utama. Sementara itu, pendapatan lain seperti dari mudharabah muqayyadah (investasi terikat) dan jasa keuangan dimasukkan ke dalam laporan laba rugi sebagai pendapatan operasi lainnya (Ascarya, 2015).

Aktivitas bank syariah tidak terlepas dari gejala makroekonomi. Gejala makroekonomi yang terjadi pada setiap Negara dapat mengganggu aktivitas ekonomi yang dilaksanakan oleh Negara. Seperti halnya dengan inflasi dan suku bunga. Meskipun sejarah bank syariah tahun 1998 tahan akan krisis yang terjadi sejak itu, namun aktivitasnya tetap terganggu sama hal nya dengan kegiatan ekonomi lainnya. Inflasi merupakan gejala makroekonomi yang sangat mempengaruhi jalannya perekonomian Negara. Inflasi adalah kenaikan terus menerus dalam tingkat harga suatu perekonomian akibat adanya kenaikan permintaan agregat atau penawaran agregat (Eachern, 2000). Sedangkan menurut Sukirno (2004) inflasi yaitu kenaikan dalam harga barang dan jasa, yang terjadi karena permintaan bertambah lebih besar dibandingkan dengan penawaran barang di pasar. Jadi inflasi merupakan kenaikan harga yang terjadi karena permintaan yang banyak namun penawaran atas barang dan jasa tersebut sedikit. Gejala makroekonomi ini mempengaruhi besar kecilnya return yang diterima oleh nasabah. Semakin besarnya persentase inflasi maka semakin banyaknya masyarakat yang menggunakan uangnya untuk kebutuhan dengan biaya-biaya yang melambung tinggi. Inflasi juga mempengaruhi kegiatan produksi yang 
Tri Inda Fadhila Rahma: Pengaruh Inflasi dan Suku Bunga

dilakukan oleh para pengusaha. Biaya-biaya produksi akan semakin meningkat sehingga menyebabkan penurunan modal oleh pengusaha. Peningkatan biaya tersebut membuat pengusaha untuk menambah modalnya dengan mengajukan peminjaman atau pun pembiayaan pada bank. Inflasi mendorong peningkatan suku bunga sehingga pengusaha beralih kepada bank syariah dengan pembiayaan tanpa bunga melainkan dengan sistem bagi hasil. Hal ini akan menyebabkan peningkatan return yang diterima oleh bank syariah dan meningkatkan return yang akan diberikan oleh bank syariah kepada masyarakat deposito maupun tabungan.

Kebijakan moneter yang dilakukan oleh bank sentral akan mempengaruhi perkembangan suku bunga, yakni salah satunya akan mempengaruhi suku bunga jangka pendek seperti suku bunga SBI. Kemudian perubahan ini akan memberikan pengaruh suku bunga deposito yang ditawarkan bank konvensional kepada masyarakat penabung dan pada suku bunga kredit yang dibebankan bank konvensional kepada para debiturnya (Pohan, 2008). Para pengusaha hanya akan melaksanakan keinginan untuk menanam modal apabila tingkat pengembalian modal dari investasi yang dilakukan, yaitu persentasi keuntungan yang akan diperoleh sebelum dikurangi bunga uang yang dibayar, lebih besar dari bunga (sukirno, 2004). Ketika bank konvensional menawarkan tingkat bunga yang lebih rendah daripada bagi hasil yang ditawarkan oleh bank syariah, maka nasabah yang kekurangan dana akan melakukan peminjaman uang pada bank konvensional. Namun apabila bank konvensional menawarkan tingkat suku bunga yang lebih tinggi daripada bagi hasil pembiayaan yang ditawarkan oleh bank syariah, maka nasabah akan melakukan pembiayaan pada bank syariah. Hal ini menyebabkan semakin banyaknya masyarakat yang melakukan pembiayaan kepada bank syariah maka semakin terlaksana pengelolaan modal oleh bank syariah dan semakin banyaknya modal yang dikelola maka semakin besar pendapatan yang diperoleh oleh bank syariah dari nasabah penyaluran dana atau pembiayaan. Maka bagi hasil yang diberikan kepada nasabah penghimpunan dana atau deposito maupun tabungan akan semakin tinggi.

Gejala inflasi dan suku bunga mempengaruhi besar kecilnya return yang diterima oleh bank syariah. Fluktuasi bagi hasil dapat dilihat pada gambar grafik di bawah ini. 


\section{Grafik Fluktuasi Bagi Hasil Bank Syariah di Indonesia}

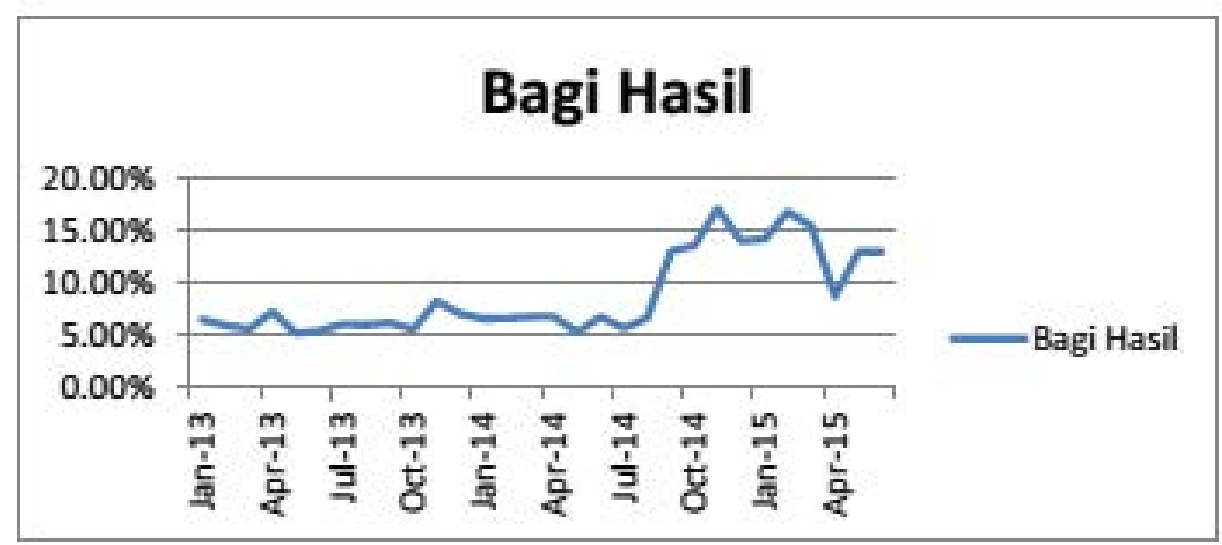

Sumber: Bank Indonesia, www.bi.go.id.

Dari gambar di atas dapat di lihat peningkatan yang terjadi di akhir tahun 2014 dan di awal tahun 2015. Pada bulan Oktober 2014 inflasi sebesar 0,47\% dan mengalami kenaikan sebesar 1,5\% di bulan November 2014. Sedangkan suku bunga mengalami peningkatan dari $7,5 \%$ menjadi $7,75 \%$.

Permasalahan di atas perlu dilakukan penelitian untuk melihat seberapa besar pengaruh makroekonomi yakni inflasi dan suku bunga terhadap bagi hasil bank syariah. Oleh sebab itu, penulis tertarik untuk melakukan penelitian "PENGARUH INFLASI DAN SUKU BUNGA TERHADAP BAGI HASIL BANK SYARIAH DI INDONESIA”. Berdasarkan latar belakang masalah di atas, maka tujuan penelitian ini untuk melihat pengaruh inflasi dan suku bunga berpengaruh terhadap bagi hasil bank syariah di Indonesia dan seberapa besar elastisitas pengaruh inflasi dan suku bunga terhadap bagi hasil bank syariah di Indonesia.

Bagi hasil menurut terminologi asing (bahasa Inggris) dikenal dengan profit sharing. Profit dalam kamus ekonomi diartikan pembagian laba.Secara definisi profit sharing diartikan "distribusi beberapa bagian dari laba pada pegawai dari suatu Perusahaan". Menurut Antonio, bagi hasil adalah suatu sistem pengolahan dana dalam perekonomian Islam yakni pembagian hasil usaha antara pemilik modal (shahibul maa/) dan pengelola (Mudharib) (Antonio, 2011).

Sedangkan menurut Vietzal (2010) bagi hasil adalah bentuk return (perolehan aktivitas usaha) dari kontrak investasi dari waktu ke waktu, tidak pasti dan tidak tetap pada bank islam. Besar kecilnya perolehan itu tergantung pada hasil usaha yang benar-benar diper 
Tri Inda Fadhila Rahma: Pengaruh Inflasi dan Suku Bunga

oleh bank islam. Jadi bagi hasil dalam penelitian ini adalah persentase bagi hasil deposito $>12$ bulan rata-rata bank syariah yang ada di Indonesia.

Metode bagi hasil terdiri dari dua sistem antara lain sebagai berikut (Saparuddin, 2009):

a) Bagi untung (Profit Sharing) adalah bagi hasil yang dihitung dari pendapatan setelah dikurangi biaya pengelolaan dana. Dalam sistem syariah pola ini dapat digunakan untuk keperluan distribusi hasil usaha lembaga keuangan syariah;

b) Bagi hasil (Revenue Sharing) adalah bagi hasil yang dihitung dari total pendapatan pengelolaan dana. Dalam sistem syariah pola ini dapat digunakan untuk keperluan distribusi hasil usaha lembaga keuangan syariah.

\section{Inflasi}

Pada umumnya inflasi diartikan sebagai kenaikan jumlah uang beredar atau kenaikan likuiditas dalam sebuah perekonomian.Pengertian tersebut mengacu pada gejala umum yang ditimbulkan oleh adanya kenaikan jumlah uang beredar di masyarakat yang diduga telah menyebabkan terjadinya kenaikan harga-harga.Dalam perkembangan lebih lanjut, inflasi secara singkat Inflasi dapat didefenisikan sebagai kecenderungan menaiknya harga-harga barang dan jasa secara umum berlangsung terus-menerus (Suseno, dkk, 2009). Inflasi dapat diartikan sebagai kenaikan terus menerus dalam tingkat harga suatu perekonomian akibat adanya kenaikan permintaan agregat atau penawaran agregat (Eachern, 2000). Sedangkan menurut Sadono Sukirno, inflasi yaitu kenaikan dalam harga barang dan jasa, yang terjadi karena permintaan bertambah lebih besar dibandingkan dengan penawaran barang di pasar (Sukrino, 2004).

Dalam Islam tidak dikenal dengan inflasi, karena mata uang yang dipakai adalah dinar dan dirham, yang mana mempunyai nilai yang stabil dan dibenarkan dalam islam (Huda, 2009). Penurunan dinar atau dirham dapat mungkin, yaitu ketika nilai emas yang menopang nilai nominal dinar itu mengalami penurunan.Diantaranya akibat ditemukannya emas dalam jumlah yang besar, tapi keadaan ini kecil sekali kemungkinannya.

Dari beberapa indikator di atas, maka dalam penelitian ini persentase laju inflasi di lihat dari Indeks Harga Konsumen. Jadi inflasi merupakan kenaikan harga yang terjadi karena permintaan yang banyak namun penawaran atas barang dan jasa tersebut sedikit. Inflasi merupakan gejala makroekonomi yang sangat mempengaruhi jalannya perekonomian Negara. Gejala makroekonomi ini mempengaruhi besar kecilnya return yang diterima oleh nasabah. Semakin besarnya persentase inflasi maka semakin banyaknya masyarakat 
j-EBIS Vol. 3 No. 1 April 2018

yang menggunakan uangnya untuk kebutuhan dengan biaya-biaya yang melambung tinggi.Inflasi juga mempengaruhi kegiatan produksi yang dilakukan oleh para pengusaha. Biaya-biaya produksi akan semakin meningkat sehingga menyebabkan penurunan modal oleh pengusaha. Peningkatan biaya tersebut membuat pengusaha untuk menambah modalnya dengan mengajukan peminjaman atau pun pembiayaan pada bank.Inflasi mendorong peningkatan suku bunga sehingga pengusaha beralih kepada bank syariah dengan pembiayaan tanpa bunga melainkan dengan sistem bagi hasil. Hal ini akan menyebabkan peningkatan return yang diterima oleh bank syariah dan meningkatkan return yang akan diberikan oleh bank syariah kepada masyarakat deposito maupun tabungan.

\section{Suku Bunga}

Bunga bank dapat diartikan sebagai balas jasa yang diberikan oleh bank berdasarkan prinsip konvensional kepada nasabah yang membeli atau menjual produknya. Bunga juga dapat diartikan sebagai harga yang harus dibayar kepada nasabah (yang memiliki simpanan) dan yang harus dibayar oleh nasabah kepada bank (nasabah yang memperoleh pinjaman) (Kasmir, 2003).

Suku bunga dalam penelitian ini adalah suku bunga BI Rate.BI Rate adalah suku bunga kebijakan yang mencerminkan sikap atau stance kebijakan moneter yang ditetapkan oleh Bank Indonesia dan diumumkan kepada publik. BI Rate diumumkan oleh Dewan Guubernur Bank Indonesia setiap rapat Dewan Gubernur bulanan dan diimplementasikan pada operasi moneter yang dilakukan Bank Indonesia melalui pengelilaan likuiditas (liquidity management) di pasar uang untuk mencapai sasaran operasional kebijakan moneter.

\section{Metodologi Penelitian}

Penelitian ini merupakan penelitian kuantitatif. Data yang dikumpulkan selama 3 tahun yaitu dari bulan Januari tahun 2013 sampai bulan Juni tahun 2015. Metode analisis data yang digunakan dalam penelitian ini, yaitu metode analisis regresi linier berganda. Metode tersebut digunakan untuk meramalkan pengaruh dari suatu variabel terikat (Bagi Hasil Bank Syariah) berdasarkan variabel bebas (Inflasi dan Suku Bunga). Data yang diperoleh kemudian di analisis dengan analisis regresi berganda, dengan menggunakan program EVIEWS 7, kemudian dijelaskan secara deskriptif.

Penelitian selanjutnya di uji dengan uji model asumsi klasik yang terdiri dari pertama, uji 
Tri Inda Fadhila Rahma: Pengaruh Inflasi dan Suku Bunga

multikolinearitas, yakni apabila terjadi multikolinear apalagi kolinear sempurna (koefisien korelasi antarvariabel bebas $=1$ ), maka koefisien regresi dari variabel bebas tidak dapat ditentukan dan standar errornya tidak terhingga (Suharyadi, dkk, 2009). Kedua, Uji Autokrelasi merupakan korelasi antara anggota observasi yang disusun menurut urutan waktu. Ketiga, Uji normalitas digunakan untuk mengetahui apakah dalam model regresi variabel pengganggu atau residual memiliki distribusi normal.

Setelah data di uji dengan uji asumsi klasik maka di uji dengan uji statistik antara lain, pertama, koefisien determinasi majemuk (R2) pada intinya mengukur seberapa jauh kemampuan model dalam menerangkan variasi variabel terikat. Digunakan untuk mengukur besarnya kontribusi atau pengaruh variabel bebas terhadap variasi naik turunnya variabel terikat. Nilai koefisien determinasi berada antara o sampai 1. Kedua, Uji F atau uji signifikansi simultan, pada dasarnya menunjukkan apakah semua variabel bebas yang dimasukkan dalam model mempunyai pengaruh secara bersama-sama terhadap variabel terikat. Artinya apakah suatu variabel independen bukan merupakan penjelas yang signifikan terhadap variabel independen (Kuncoro, 2003). Uji F statistik dalam regresi berganda dapat di lihat pada tabel hasil estimasi. Apabila prob(F-statistic) lebih kecil dari taraf nyata sebesar $5 \%$ atau 0,05 maka dinyatakan bahwa secara bersama-sama variabel bebas mempengaruhi variable terikat. Namun apabila prob(F-statistic) lebih besar dari taraf nyata $5 \%$ atau 0,05 maka tidak adanya pengaruh dari variabel bebas secara bersama-sama mempengaruhi variabel terikat. Ketiga, Uji t merupakan uji signifikansi parsial atau individual digunakan untuk menguji apakah suatu variabel bebas berpengaruh atau tidak terhadap variabel terikat (Suharyadi, 2009). Uji t dapat di lihat pada tabel hasil estimasi dari masing-masing probability variabel.Apabila probability lebih kecil dari taraf nyata $5 \%$ maka adanya pengaruh variabel tersebut terhadap variabel terikat.Dan apabila lebih besar dari taraf nyata 5\% maka tidak adanya pengaruh variabel tersebut terhadap variabel terikat.

\section{Hasil Penelitian dan Pembahasan}

Hasil penelitian menunjukkan bahwa persamaan regresi dalam penelitian ini

Dari persamaan regresi di atas di analisis dengan analisis regresi berganda dengan menggunakan program Eviews Versi 7. Sebelum di analisis dilakukan uji asumsi klasik. Berikut uji model dari persamaan regresi di atas. 


\section{Uji Model}

Analisis data dilakukan dengan menggunakan analisis regresi linier berganda dengan bantuan program komputer Eviews Versi 7.Untuk mendapatkan estimasi yang terbaik, terlebih dahulu data sekunder tersebut harus dilakukan pengujian asumsi klasik yaitu uji multikolinearitas, uji autokorelasi dan uji normalitas. Berikut hasil uji multikolieritas:

\section{Tabel 1. Hasil Uji Multikolinearitas}

Variance Inflation Factors

Date: 01/13/17 Time: 10:40

Sample: 2013M01 2015M06

Included observations: 30

$\begin{array}{cccc}\text { Variable } & \begin{array}{c}\text { Coefficient } \\ \text { Variance }\end{array} & \begin{array}{c}\text { Uncentered } \\ \text { VIF }\end{array} & \begin{array}{c}\text { Centered } \\ \text { VIF }\end{array} \\ & & & \\ \text { C } & 0.004470 & 107.8130 & \text { NA } \\ \text { INF } & 7.08 \mathrm{E}-05 & 1.572978 & 1.012600 \\ \text { SBI } & 8.56 \mathrm{E}-05 & 105.5576 & 1.012600\end{array}$

\section{Sumber : Data sekunder yang diolah dengan Eviews}

Dari tabel hasil estimasi model regresi (tabel) dapat dilihat bahwa VIF < 10. Maka dapat dinyatakan bahwa hasil estimasi model regresi dalam penelitian ini tidak mengandung gejala multikolinieritas. Penelitian selanjutnya diuji autokolerasi yang dapat dilihat dari hasil pengujian Breusch-Godfrey Serial Correlation LM Test (BGLM)

Tabel 2. Hasil Pengujian Breusch-Godfrey Serial Correlation LM Test (BGLM)

Breusch-Godfrey Serial Correlation LM Test:

$\begin{array}{llll}\text { F-statistic } & 18.21712 & \text { Prob. F(2,25) } & 0.0000 \\ \text { Obs }{ }^{*} \text { R-squared } & 17.79182 & \text { Prob. Chi-Square(2) } & 0.0001\end{array}$


Test Equation:

Dependent Variable: RESID

Method: Least Squares

Date: 01/13/17 Time: 13:46

Sample: 2013M01 2015M06

Included observations: 30

Presample missing value lagged residuals set to zero.

$\begin{array}{ccccc}\text { Variable } & \text { Coefficient } & \text { Std. Error } & \text { t-Statistic } & \text { Prob. } \\ & & & & \\ & & & & \\ \text { C } & 0.006961 & 0.044406 & 0.156754 & 0.8767 \\ \text { INF } & -0.005213 & 0.005647 & -0.923119 & 0.3648 \\ \text { SBI } & 0.001526 & 0.006149 & 0.248229 & 0.8060 \\ \text { RESID(-1) } & 0.733518 & 0.197121 & 3.721156 & 0.0010 \\ \text { RESID(-2) } & 0.077540 & 0.199650 & 0.388378 & 0.7010\end{array}$

$\begin{array}{lllr}\text { R-squared } & 0.593061 & \text { Mean dependent var } & -3.61 \mathrm{E}-17 \\ \text { Adjusted R-squared } & 0.527950 & \text { S.D. dependent var } & 0.034030 \\ \text { S.E. of regression } & 0.023381 & \text { Akaike info criterion } & -4.522816 \\ \text { Sum squared resid } & 0.013666 & \text { Schwarz criterion } & -4.289283 \\ \text { Log likelihood } & 72.84223 & \text { Hannan-Quinn criter. } & -4.448106 \\ \text { F-statistic } & 9.108558 & \text { Durbin-Watson stat } & 2.009187 \\ \text { Prob(F-statistic) } & 0.000111 & & \end{array}$

\section{Sumber: Data sekunder yang diolah dengan Eviews}

Dari tabel 2 terlihat, statistik uji $N R^{2}$ (Obs*R-squared) memberikan nilai 17,79182 dannilai p value bagi statistik ini adalah 0,0001, lebih rendah dari level of significance 5\%. Dengan demikian dapat disimpulkan bahwa dari hasil pengujian Breusch-Godfrey Serial Correlation LM Test (BGLM) hasil estimasi model regresi dalam penelitian ini tidak mengandung autokorelasi.

Model regresi yang baik adalah distribusi data normal atau mendekati normal.Uji normal 
itas digunakan untuk mengetahui apakah dalam sebuah model regresi, variabel dependen, variabel independen, atau keduanya mempunyai distribusi normal atau tidak.Untuk menguji normal data ini menggunakan uji Jarque-Bera (J-B Test) dengan hasil olahan data Eviews. Berikut hasil olah data dengan Eviews:

Tabel 3. Uji Normalitas Jarque-Bera (J-B Test)

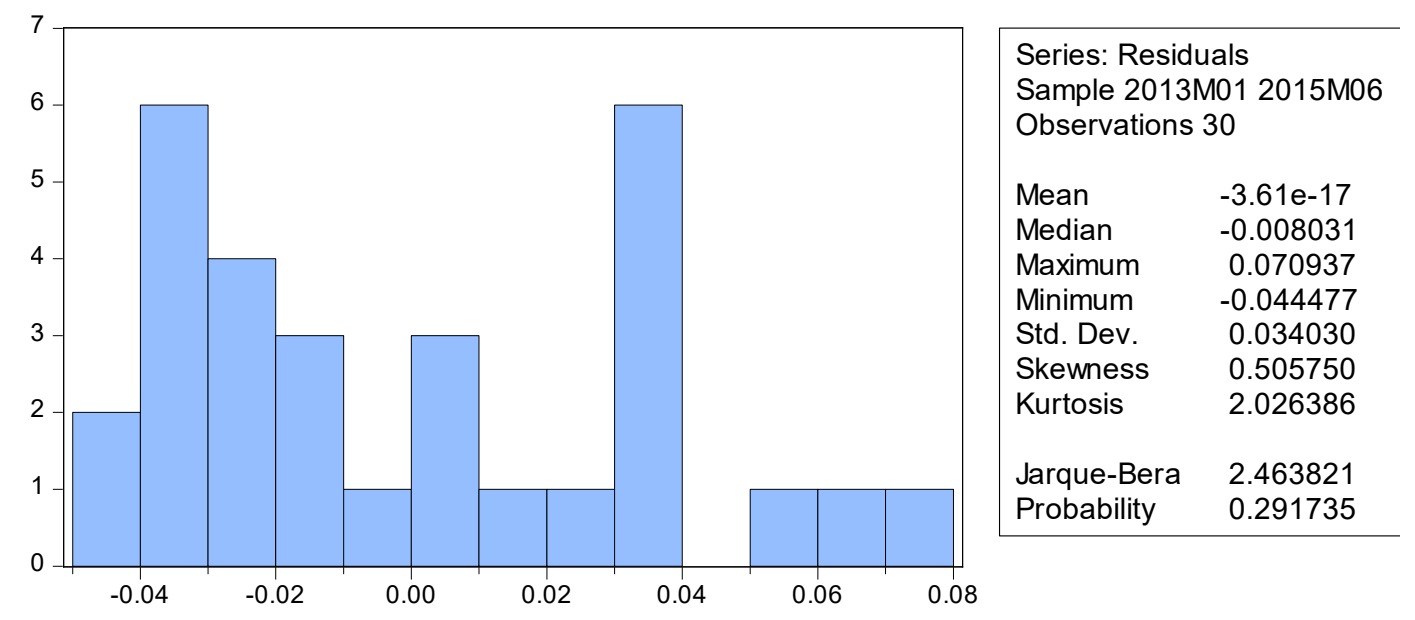

Sumber : Data sekunder yang diolah dengan Eviews

Dari tabel 3 terlihat bahwa nilai Probability adalah 0,291735. Oleh karena nilai Probability> 0,05 maka dapat disimpulkan data terdistribusi normal.

\section{Uji Statistik}

Dari penelitian yang dilakukan oleh peneliti, maka hasil estimasi model regresi yang diteliti dapat dilihat sebagai berikut:

\section{Tabel 4. Hasil Estimasi Model Regres}

Dependent Variable: BHS

Method: Least Squares

Date: 01/13/17 Time: 13:52

Sample: 2013M01 2015M06

Included observations: 30

Variable $\begin{array}{r}\text { Coeffi- } \\ \text { cient Std. Error t-Statistic Prob. }\end{array}$




$\begin{array}{cllll}\text { C } & 0.105559 & 0.066858 & 1.578860 & 0.1260 \\ \text { INF } & 0.001995 & 0.008417 & 0.237004 & 0.8144 \\ \text { SBI } & 0.027078 & 0.009251 & 2.927052 & 0.0069\end{array}$

$\begin{array}{lll}\text { R-squared } & 0.241056 & \text { Mean dependent var } \\ \text { Adjusted R-squared } & 0.184838 & \text { S.D. dependent var } \\ \text { S.E. of regression } & 0.035268 & \text { Akaike info criterion } \\ \text { Sum squared resid } & 0.033583 & \text { Schwarz criterion } \\ \text { Log likelihood } & 59.35586 & \text { Hannan-Quinn criter. } \\ \text { F-statistic } & 4.287872 & \text { Durbin-Watson stat } \\ \text { Prob(F-statistic) } & 0.024145 & \end{array}$

\section{Sumber: Data sekunder yang diolah dengan Eviews}

Tabel hasil estimasi model regresi menunjukkan nilai R square sebesar 0.241056 . Hal ini menunjukkan bahwa inflasi dan suku bunga mampu menerangkan variasi Bagi Hasil Bank Syariah sebesar $24,10 \%$. Sedangkan sisanya sebesar $75,9 \%$ dijelaskan oleh variabel lain di luar model.Nilai $\mathrm{R}^{2}$ di atas sangat kecil sehingga variable inflasi dan suku bunga terbatas dalam menerangkan variable Bagi Hasil Bank Syariah.

Dilihat dari hasil estimasi di atas bahwa nilai probability adalah sebesar 0.024145 dan nilai $F$ hitung sebesar 4.287872. Dasar pengambilan keputusan adalah tingkat signifikansi sebesar $5 \%$ atau 0,05. Karena nilai probability lebih kecil dari 0,05 maka $\mathrm{H}_{0}$ ditolak dan hal ini menunjukkan adanya pengaruh inflasi dan suku bunga secara simultan terhadap Bagi Hasil Bank Syariah.

Sedangkan hasil uji t pada penelitian ini bahwa nilai probability pada variable inflasi sebesar 0.8144 lebih besar dari taraf nyata 0,05, maka Ho diterima. Hal ini menunjukkan bahwa tidak terdapat pengaruh yang signifikan antara inflasi terhadap Bagi Hasil Bank Syariah. Sehingga perubahan tingkat inflasi tidak mempengaruhi fluktuasi Bagi Hasil Bank Syariah. Sedangkan variabel suku bunga nilai probability sebesar 0.0069 lebih kecil dari taraf nyata sebesar 0.05, maka Ho ditolak. Hal ini menunjukkan bahwa terdapat 
j-EBIS Vol. 3 No. 1 April 2018

pengaruh yang signifikan antara suku bunga dengan Bagi Hasil Bank Syariah. Sehingga perubahan tingkat suku bunga mempengaruhi perubahan Bagi Hasil Bank Syariah.

Berdasarkan pengujian yang dilakukan secara signifikan membuktikan bahwa secara parsial inflasi tidak berpengaruh terhadap bagi hasil bank syariah di Indonesia. Dari hasil pengujian tersebut menandakan bahwa Bank Syariah di Indonesia tetap berkompeten dan tidak terkena imbas gejala ekonomi seperti inflasi meskipun terjadi fluktuasi inflasi namun tidak akan terjadi perubahan besarnya bagi hasil yang diterima oleh nasabah Bank Syariah di Indonesia. Karena bagi hasil berasal dari seberapa besar hasil pengelolaan modal yang disalurkan kepada masyarakat dan Bank Syariah membagikan keuntungan hasil dari penyaluran dananya kepada nasabah deposan maupun tabungan. Hal ini sejalan dengan peristiwa krisis moneter yang terjadi pada tahun 1998. Bank syariah tetap berdiri walaupun pada saat itu terjadinya krisis, padahal bank-bank konvensional pada saat itu banyak yang mengalami kebangkrutan.

Sedangkan suku bunga berpengaruh positif dan signifikan terhadap bagi hasil bank syariah di Indonesia. Penelitian ini mendukung teori yang menyatakan bahwa pengaruh suku bunga deposito yang ditawarkan bank konvensional kepada masyarakat penabung dan pada suku bunga kredit yang dibebankan bank konvensional kepada para debiturnya (Pohan, 2008). Para pengusaha hanya akan melaksanakan keinginan untuk menanam modal apabila tingkat pengembalian modal dari investasi yang dilakukan, yaitu persentasi keuntungan yang akan diperoleh sebelum dikurangi bunga uang yang dibayar, lebih besar dari bunga (Sukirno, 2004). Ketika bank konvensional menawarkan tingkat bunga yang lebih rendah daripada bagi hasil yang ditawarkan oleh bank syariah, maka nasabah yang kekurangan dana akan melakukan peminjaman uang pada bank konvensional. Namun apabila bank konvensional menawarkan tingkat suku bunga yang lebih tinggi daripada bagi hasil pembiayaan yang ditawarkan oleh bank syariah, maka nasabah akan melakukan pembiayaan pada bank syariah. Hal ini menyebabkan semakin banyaknya masyarakat yang melakukan pembiayaan kepada bank syariah maka semakin terlaksana pengelolaan modal oleh bank syariah dan semakin banyaknya modal yang dikelola maka semakin besar pendapatan yang diperoleh oleh bank syariah dari nasabah penyaluran dana atau pembiayaan. Maka bagi hasil yang diberikan kepada nasabah penghimpunan dana atau deposito maupun tabungan akan semakin tinggi. Sehingga variabel suku bunga BI Ratedapat dijadikan patokan dalam memprediksi Bagi Hasil Bank Syariah di Indonesia.Hal ini menunjukkan bahwa Bank Syariah harus lebih berkompeten dalam mengelola 12 
Tri Inda Fadhila Rahma: Pengaruh Inflasi dan Suku Bunga

dana masyarakat serta menyalurkan dana dengan lebih aktif lagi agar dapat memberikan return yang besar untuk masyarakat yang dihimpun dananya, namun tetap tidak mengabaikan prinsip kehalalan perbankan syariah. Sehingga menimbulkan kepercayaan kepada bank syariah dan bank syariah menjadi pilihan dalam menanamkan modal investasi masyarakat.

\section{Kesimpulan}

Berdasarkan hasil analisis data yang telah dikemukakan sebelumnya, dapat diambil kesimpulan bahwa hasil analisis regresi linier berganda menunjukkan bahwa secara simultan variabel inflasi dan suku bunga berpengaruh terhadap bagi hasil bank syariah di Indonesia dan secara bersama-sama mempengaruhibagi hasil bank syariah di Indonesia dengan taraf kepercayaan 95\%. Hal ini dilihat dari hasil perolehan Eviews dengan $p$ value sebesar 0.0069 yang lebih kecil dari nilai a sebesar $5 \%$.

Koefesien suku bunga (SBI) terhadap bagi hasil bank syariah adalah berpengaruh positif dengan nilai koefesien sebesar 0,0271. Hal ini menunjukkan bahwa jika terjadi kenaikan suku bunga sebesar $1 \%$ maka akan meningkatkan bagi hasil bank syariah sebesar 0,0271\%. Nilai $p$ value sebesar 0,0069 yang lebih kecil dari taraf nyata sebesar 0,01, maka dapat disimpulkan bahwa terdapat pengaruh yang signifikan antara suku bunga terhadap bagi hasil bank syariah pada taraf kepercayaan 99\%. Dengan demikian, apabila terjadi peningkatan suku bunga, maka akan meningkatkan bagi hasil bank syariah.

Sedangkan inflasi (INF) secara parsial tidak berpengaruh terhadap bagi hasil bank syariah. Sehingga variabel inflasi tidak dapat dijadikan ukuran dalam menilai perubahan fluktuasi bagi hasil bank syariah.

Variasi faktor yang berpengaruh terhadap bagi hasil bank syariah dijelaskan oleh variabel independen inflasi dan suku bunga yang secara bersama-sama menjelaskan pengaruh sebesar $24,10 \%$, sedangkan sisanya sebesar 75,9\% dijelaskan oleh variabel lain yang tidak diteliti atau diluar model. 


\section{DAFTAR PUSTAKA}

Abdad,Zaidi.Lembaga Perekonomian Umat diDunia Islam.Bandung: Angkasa, 2003.

Ajija,Shochrul R. et. al., Cara Cerdas Menguasai Eviews.Jakarta : Salemba 4,2011.

Aisyah, Sinta.Faktor-Faktor yang Mempengaruhi Bagi Hasil Pada Bank Syariah Mandiri.Yogyakarta: Skripsi Universitas Islam Negeri Sunan Kalijaga, 2010.

Antonio, Muhammad Syafi'l.Bank Syariah: Teori dan Praktik. Jakarta: Gema Insani, 2011. .Bank Syari'ah; Wacana Ulama' dan Cendekiawan. Jakarta: Tazkia Institut dan Bank Indonesia, 1999.

Arif,M. Nur Rianto Al.Teori Makroekonomi Islam (Konsep, Teori dan Analisis).Bandung: Alfabeta, 2010.

Ascarya.Akad dan Produk Bank Syariah.Jakarta, Raja Grafindo Persada, 2015.

Muhammad Ayub, Understanding Islamic Finance, terj. Aditya Wisnu Pribadi, Keuangan Syariah. Jakarta: Gramedia, 2007.

Daud, Abu.Kitab: Jual Beli, Bab: Meneteapkan harga barang, No. Hadis: 2994

Direktorat Statistik Ekonomi dan Moneter, Statistik Keuangan Ekonomi Indonesia, BAB Metadata Indikator Makroekonomi (Bank Indonesia: http://www.bi.go.id/).

Eachern,Mc.Ekonomi Makro Pendekatan Kontemporer.Jakarta: Salemba Empat, 2000.

Efferin, Sujuko et. al., Metode Penelitian Akuntansi.Yogyakarta: Graha Ilmu 2008.

Gunawan, Fandi.Perkembangan Moneter 2013, Macroeconomic Dashboard, http://macroeconomicdashboard.com/index.php/id/moneter/138-perkembangan-moneter-2013-iii.

Huda, Nurul et.al.Ekonomi Makro Islam : Pendekatan Teoritis. Jakarta : Kencana 2009.

Karim, Adiwarman A. Ekonomi Makro Islami (Jakarta: Rajawali Pers, 2010.

Kasmir.Bank dan Lembaga Keuangan. Jakarta : PT. Raja Grafindo Persada, 2003.

Kuncoro, Mudrajat.Metode Riset untuk Bisnis dan Ekonomi: Bagaimana Meneliti dan Menulis Tesis?.Jakarta: Erlangga, 2003.

Majah, Ibnu.Kitab: Perdagangan, Bab: Penimbunan dan Importir, No. Hadis: 2144 
Tri Inda Fadhila Rahma: Pengaruh Inflasi dan Suku Bunga

Manurung, Jonni et. al., Ekonomi Keuangan dan kebijakan Moneter.Jakarta: Penerbit Salemba Empat, 2009.

Mardani.Fiqh Ekonomi Syariah. Jakarta: Kencana Prenadamedia Group, 2013.

Muslichs,Ahmad Wardi.Fiqih Muamalah.Jakarta: Bumi Aksara, 2015.

Muhammad. Manajemen Dana Bank Syariah.Jakarta: Rajawali Pers, 2014.

Pohan, Aulia.Kerangka Kebijakan Moneter dan Implementasinya di Indonesia.Jakarta: PT RajaGrafindo Persada, 2008.

Rosadi, Dedi.Ekonometrika dan Analisis Runtun Waktu Terapan dengan Eviews.Yogyakarta: Andi Offset, 2012.

Rivai,Veithzal.Islamic Banking: Sebuah Teori, Konsep dan Aplikasi.Jakarta : PT.Bumi Aksara, 2010.

Siregar, Saparuddin.Diktat Akuntansi Perbankan Syariah.Fakultas Syariah IAIN Sumatera Utara, 2009.

Suharyadi dan Purwanto S. K, Statistika:Untuk Ekonomi dan Keuangan Modern Edisi 2. Jakarta: Penerbit Salemba Empat, 2009.

Sukirno,Sadono.Makroekonomi : Teori Pengantar, ed. Ke-3, cet. Ke-15. Jakarta: PT RajaGrafindo Persada, 2004.

Susanti, Hera.Indikator-Indikator Makroekonomi.Jakarta: LPFE Universitas Indonesia, 2000.

Suseno dan Siti Aisyah.Inflasi.Jakarta : Pusat Pendidikan dan Studi Kebanksentralan (PPSK) Bank Indonesia, Seri Kebansentralan No. 22, 2009.

Tarigan,Azhari Akmal, et. al., Dasar-dasar Ekonomi Islam.Bandung, CitaPustaka Media, 2006.

Tim Pengembangan Perbankan Syariah Institut Bankir Indonesia.Bank Syariah : Konsep, Produk dan Implementasi Operasional. Jakarta: Djambatan, 2003. 